\title{
FAKTOR PENYEBAB PENURUNAN KINERJA KARYAWAN OUTSOURCING SUBBAGIAN PENGELOLAAN PIUTANG: STUDI PADA PT. PLN UP3 TELUK NAGA TANGERANG
}

\author{
Yanri Daya Pandera; Syarif Ali; dan Wahyudi \\ Universitas Pembangunan Nasional Veteran Jakarta \\ Email korespondensi: yandri.dp@upnvj.ac.id \\ http://dx.doi.org/10.21460/jrmb.2021.162.396
}

\begin{abstract}
ABSTRAK
Penelitian ini bertujuan untuk mengetahui dan menganalisis penyebab penurunan kinerja karyawan outsourcing subbagian pengelolaan piutang PT PLN (Persero) UP3 Teluk Naga Tangerang. Penelitian ini menggunakan metode kualitatif dengan pendekatan studi kasus, teknik pengumpulan data dalam penelitian ini dilakukan dengan metode wawancara, observasi, dan dokumentasi. Wawancara dilakukan secara semi terstruktur dengan partisipan yang diantaranya adalah supervisor subbagian pengelolaan piutang, koordinator karyawan subbagian pengelolaan piutang, dan perwakilan karyawan outsourcing subbagian pengelolaan piutang. Untuk membuktikan keabsahan data dalam penelitian, peneliti menggunakan metode triangulasi data, dan selanjutnya data dianalisis dengan melakukan reduksi data, penyajian data, dan penarikan kesimpulan. Hasil penelitian menemukan tiga faktor utama yaitu, keterampilan \& keahlian, kepemimpinan, serta beban kerja yang saling memiliki keterikatan terhadap faktor lainnya sikap kerja, motivasi, kepuasan kerja, loyalitas, dengan perannya masingmasing sebagai penyebab dari penurunan kuantitas kinerja karyawan outsourcing subbagian pengelolaan piutang PT PLN (Persero) UP3 Teluk Naga Tangerang yang disebabkan adanya kondisi pandemi Covid-19.
\end{abstract}

Kata Kunci: kinerja karyawan, karyawan outsourcing, PT.PLN, pandemi covid-19

\begin{abstract}
This study aims to determine and analyze the cause of the decline in the performance of outsourcing employees in the recieveable management sub-section of PT PLN (Persero) UP3 Teluk Naga. This research uses a qualitative method with a case study approach, data collection techniques in this study were conducted by interview, observation, and documentation methods. Interviews were conducted in a semi-structured manner with five participants, including supervisor of the accounts receivable management sub-section, coordinators of the accounts receivable management sub-section, and representatives of outsourced employees of the accounts receivable management sub-section. To prove the validity of the data in the study, the researcher used the data triangulation method, and then the data was analyzed by performing data reduction, data presentation, and conclusions. The results of the study found three factors, namely skills \& expertise, leadership, and workload which have a mutual attachment to other factors, namely work attitude, motivation, job statisfaction, employee loyalty, with their respective roles as the cause of the decrease in the quantity of the employee performance outsourcing sub-section management of accounts receivable PT PLN (Persero) UP3 Teluk Naga Tangerang, which was triggered by the Covid-19 pandemic condition.
\end{abstract}

Keywords: employee performance, outsourcing employee, PT PLN, Covid-19 pandemic 


\section{PENDAHULUAN}

Manusia melambangkan satu dari sumber daya mengusai peran penting dikarenakan manusia itu sendiri yang merupakan pelaku utama dalam setiap bentuk aktivitas, baik dari pemanfaatan sumber daya lainnya, penciptaan atau menjalankan teknologi, atau bahkan dalam melakukan pengelolaan sumber daya manusia itu sendiri. Sumber daya manusia menjadi satu berharga suatu organisasi hingga perusahaan yang dimana memiliki peranan penting untuk memastikan berjalannya suatu organisasi atau perusahaan tersebut. Strategi-strategi dan upaya yang optimal perlu dilakukan oleh berbagai pihak perusahaan yang saling berkesinambungan terutama pihak manajerial dalam melakukan pengelolaan SDM secara profesional agar dapat termanfaatkan secara baik, efektif, dan efisien, sehingga dapat memberikan kontribusi terhadap pencapaian tujuan perusahaan tersebut.

Keberhasilan dari pengelolaan sumber daya manusia akan tercerminkan dari hasil kinerja atau kontribusi karyawan terhadap perusahaan, seperti yang diungkapkan oleh (Adamy, 2016 hlm.91) bahwa kinerja karyawan sama dengan berapa karyawan memberi kontribusi pada organisasi antara lain kuantitas output, kualitas output, jangka waktu output, kehadiran ditempat kerja dan juga sikap koperatif. Jadi tinggi atau rendahnya kemampuan dan keterampilan pegawai akan berpengaruh terhadap produktivitas karyawan itu sendiri yang dimana akan berdampak langsung pula terhadap perusahaan, dimana karyawan dengan kinerja yang baik akan memberikan kontribusi positif bagi perusahaan begitu pula sebaliknya karyawan dengan kinerja yang kurang baik akan memberikan kontribusi negatif bagi perusahaan.

Seluruh organisasi atau perusahaan kecil berlanjut perusahaan besar ataupun perusahaan milik negara seperti PT PLN (Persero), sangat berharap akan indikator-indikator kinerja dalam segi kualitas maupun kuantitas terus terjaga dan atau terus semakin membaik, pernyataan sejalan dengan yang diungkapkan (Indrasari, 2017 hlm.57) bahwasanya kinerja isu aktual organisasi sebab apapun organisasinya kinerja merupakan kunci terhadap efektivitas keberhasilan organisasi. PT Perusahaan Listrik Negara (Persero) atau biasa disingkat PT PLN merupakan salah satu perusahaan negara atau biasa disebut badan usaha milik negara (BUMN) yang bergerak dibidang penyediaan energi listrik dengan lini bisnis antara lain yaitu pembangkitan listrik, penyaluran energi listrik, distribusi listrik, serta pelayanan pelanggan. PT PLN memiliki visi untuk menjadi perusahaan listrik terkemuka seAsia Tenggara dan \#1 pilihan pelanggan untuk solusi energi.

PT PLN Unit Pelaksana Pelayanan Pelanggan (UP3) Teluk Naga Tangerang merupakan kantor PLN ranting cabang Tangerang yang berlokasi di JL. Raya Mauk Km. 12 Sepatan Tangerang. Dimana dikhususkan untuk melayani pelanggan yang jauh dari kota Tangerang terutama pelayanan daerah kabupaten bagian utara Tangerang dan memiliki tanggung jawab dalam melakukan pelayanan langsung terhadap konsumen di sembilan kecamatan kabupaten Tangerang. PT PLN (Persero) UP3 Teluk Naga Tangerang memiliki tujuh divisi bagian yang berbeda yaitu; divisi bagian perencanaan, divisi bagian jaringan, divisi bagian konstruksi, divisi bagian transaksi energi, divisi bagian niaga, divisi bagian pemasaran, dan divisi bagian keuangan, SDM, dan administrasi.

Subbagian pengelolaan piutang merupakan satu dari dua subdivisi bagian yang ada pada divisi utama bagian Niaga di PT PLN (Persero) UP3 Teluk Naga Tangerang. Subbagian pengelolaan piutang adalah divisi bagian yang memiliki job desk utama yaitu melakukan respons dan penagihan terhadap tunggakan pembayaran konsumen atas pemakaian energi listrik. Pada bagian pengelolaan piutang PT PLN (Persero) UP3 Teluk Naga Tangerang menggunakan tenaga kerja karyawan outsourcing. Tenaga kerja outsourcing yaitu suatu tenaga kerja dikontrak serta didatangkan dari luar perusahan disediakan perusahaan khusus menyediakan jasa tenaga kerja outsourcing (Filia \& Wijaya, 2019). Subbagian pengelolaan piutang menggunakan total 54 karyawan outsourcing yang berasal dari dua perusahaan penyedia outsourcing yaitu PT Kedu Jaya dan PT Shiwa dimana dalam kontrak perjanjian kerja yang diberikan karyawan outsourcing tersebut bertugas untuk melakukan respons terhadap tunggakan konsumen baik dalam bentuk pemberian surat peringatan, penyegelan listrik, 
pemutusan sementara, maupun pemutusan total.

Pada kinerja karyawan outsourcing bagian pengelolaan piutang PT PLN (Persero) UP3 Teluk Naga Tangerang, terlihat bahwa adanya suatu fenomena permasalahan dimana kinerja karyawan dalam melakukan penyelesaian lembar piutang selama periode
Agustus - Desember 2020 masih berada di bawah target yang diberikan dan sedang mengalami penurunan. Hal yang terlihat tabel data berikut:

Tabel 1. Data Pencapaian Kinerja Outsourcing Bagian Pengelolaan Piutang

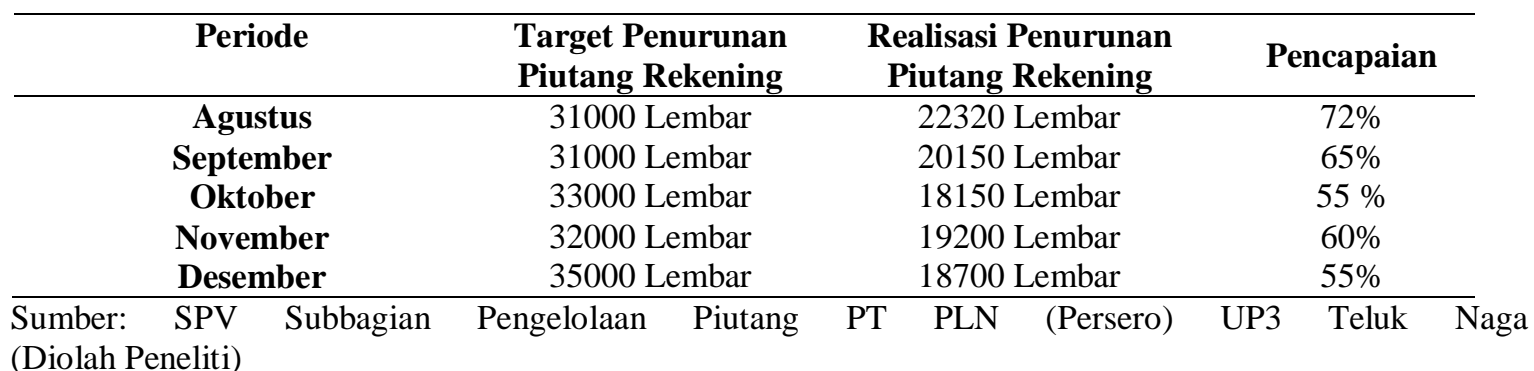

Berdasarkan tabel 1 dapat dilihat dan tergambarkan target lembar penurunan piutang rekening listrik yang harus ditindak lanjuti dan diselesaikan oleh karyawan outsourcing bagian pengelolaan piutang PT PLN (Persero) UP3 Teluk Naga Tangerang, berdasarkan data tersebut diketahui bahwa hasil pencapaian karyawan dalam realisasi penyelesaian lembar penurunan piutang rekening belum bisa mencapai hasil yang maksimal sesuai dengan yang sudah ditetapkan dan ditargetkan oleh PT PLN (Persero) UP3 Teluk Naga Tangerang. Pencapaian tertinggi dari realisasi penyelesaian lembar piutang dalam periode Agustus sampai Desember 2020 hanya menyentuh angka 72\% dan dapat dilihat pula adanya penurunan pencapaian yang cukup signifikan pada periode Agustus hingga Desember 2020. Maka dari data tersebut dapat disimpulkan bahwa adanya suatu fenomena penurunan dalam kuantitas kinerja karyawan yang dapat terlihat dari realisasi penyelesaian lembar penurunan piutang rekening listrik yang belum mencapai target dan sedang mengalami penurunan pencapaian.

Subbagian pengelolaan piutang PT PLN (Persero) UP3 Teluk Naga Tangerang, merupakan salah satu divisi bagian yang sangat penting dikarenakan job desk divisi ini yang dimana memastikan agar pemasukan perusahaan lancar dan tidak mengalami kerugian, dengan cara melakukan respon dan penagihan terhadap tunggakan pembayaran konsumen atas pemakaian energi listrik. Berdasarkan urgensi tersebut serta fenomena penurunan hasil kuantitas kinerja karyawan yang sedang terjadi, menjadikan latar belakang peneliti untuk membahas lebih dalam dan melakukan penelitian mengangkat judul penelitian "Analisis Faktor-Faktor Penyebab Penurunan Kinerja Karyawan Outsourcing Subbagian Pengelolaan Piutang PT PLN (Persero) UP3 Teluk Naga Tangerang".

Berdasarkan latar belekang tersebut maka fokus penelitian ini adalah memfokuskan dalam menganalisis penyebeab penurunan kinerja karyawan outsourcing pengelolaan piutang PT PLN (Persero) UP3 Teluk Naga Tangerang. Dengan tujuan penelitian ini adalah untuk mengetahui serta menganalisis penyebab penurunan kinerja karyawan outsourcing subbagian pengelolaan piutang PT PLN (Persero) UP3 Teluk Naga.

\section{KAJIAN LITERATUR}

\section{Manajemen Sumber Daya Manusia}

Human resource management (HRM) adalah proses memperoleh, melatih, mengevaluasi, memberi kompensasi kepada karyawan dan memperhatikan masalah hubungan ketenagakerjaan, Kesehatan, dan keselamatan, dan ekuitas mereka (Dessler, 2017). Mangkunegara dalam Sinambela (2016) mengungkapkan bahwa manajemen sumber daya manusia yaitu perencanaan, 
pengorganisasian, koordinasi, pelaksanaan hingga pengawasan, pengadaan pekerja, pengembangan, kompensasi, integrasi, pemeliharaan, dan pemisahan pekerja mencapai tujuan organisasi.

Mondy \& Martocchio (2016) menyatakan bahwa terdapat delapan fungsi atau peran manajemen sumber daya manusia yang antara lain; staffing; manajemen kinerja; pengembangan sumber daya manusia; kompensasi; hubungan terhadap karyawan; keamanan dan kesehatan; riset sumber daya manusia; dan keterkaitan fungsi manajemen sumber daya manusia. Hasibuan dalam Elbadiansyah (2019) menjelaskan opini arti yang terkait manajemen sumber daya manusia (SDM) yaitu ilmu serta seni dimana ilmu dan seni digunakan untuk membantu perusahaan mencapai tujuannya.

\section{Kinerja Karyawan}

Bernardin dikutip dari buku (Lian, 2017) mengungkapkanKinerja atau prestasi adalah catatan tentang hasil-hasil yang diperoleh dari fungsi-fungsi pekerjaan tertentu atau kegiatan tertentu selama kurun waktu tertentu. Rivai mendefinisikan kinerja sebagai 'pencapaian produktivitas karena kinerja yaitu suatu hasil dimana orang-orang hingga sumber daya lain dalam organisasi secara Bersama-sama membawa hasil akhir didasarkan pada tingkat mutu dan standar telah ditetapkan' (Rivai \& Segala, 2011). Haryono (2018) menyatakan kinerja individu yaitu 'hasil kerja seseorang yang dipengaruhi kompetensi individu, dukungan organisasi dan dukungan manajemen.' Kompetensi individu yaitu kemampuan dan keterampilan seseorang melakukan kerja. Kinerja individu itu sendiri ada yang mempengaruhi oleh beberapa faktor; pengetahuan; keterampilan kerja; sikap atau perilaku kerja; motivasi atau etos kerja; karakteristik khusus yang diperlukan pekerjaan.

Bernadin \& Russell dalam Adamy (2016) mengedepankan konsep indikator kinerja yang memuat enam standar yang dapat digunakan untuk mengukur kinerja pegawai, yaitu; quality; quantity; timelines; costefectivenese; need for supervisor; dan interpersonal impact. Robbins dalam Kawiana (2020) menyatakan kinerja sebagai fungsi antara kemampuan ability (A), motivasi motivation (M), kesempatan opportunity (O), yaitu kinerja $\mathrm{f}=(\mathrm{A} \times \mathrm{M} \times \mathrm{O})$. yang artinya kinerja adalah fungsi dari kemampuan, motivasi, dan kesempatan. Gibson, Ivancevich, dan Donnely dalam Indrasari (2017) yang menyatakan bahwa kinerja setiap individu juga merupakan kinerja organisasi, sehingga dapat dilihat bahwa kinerja karyawan memegang peranan yang sangat penting dalam perusahaan. Rummler dan Brache dalam Adamy (2016) mengemukakan bahwasanya terdapat 5 faktor yang dapat mempengaruhi kinerja yaitu: barrier; performance expectations; consequence; feedback; knowledge/skill dan individual abilities. Kasmir (2016) juga menyebutkan beberapa faktor-faktor mempengaruhi kinerja yaitu keterampilan \& keahlian, pengetahuan, rencana kerja, sikap kerja, motivasi kerja, kepemimpinan, beban kerja, kepuasan kerja, loyalitas kesetiaan, serta disiplin kerja.

\section{Deskripsi Objek yang Diteliti}

Subbagian pengelolaan piutang pada PT. PLN (Persero) UP3 Teluk Naga Tangerang merupakan salah satu subdivisi bagian yang berada di bawah langsung divisi bagian Niaga. Bagian ini memiliki tanggung jawab utama yaitu melakukan penyelesaian penurunan tunggakan rekening listrik.

\section{METODA PENELITIAN}

Pendekatan penelitian melalui pendekatan dengan metode kualitatif dengan paradigma penelitian interpretivism dengan pendekatan studi kasus, dimana menurut Menurut Conny R. Semiawan dalam Samsu (2017 hlm. 59) mengatakan bahwa 'tujuan utama dari penelitian kualitatif untuk menangkap arti (meaning/understanding) terdalam atas suatu peristiwa, gejala, fakta kejadian, realita, atau masalah tertentu bukan mempelajari/membuktikan hubungan sebab akibat atau korelasi dari suatu masalah atau peristiwa.

Lokasi dalam penelitian ini dilakukan ditempat objek melakukan pekerjaannya yaitu bertempat di daerah kabupaten Tangerang, Banten. Adapun Objek dalam penelitian ini adalah divisi Subbagian Pengelolaan Piutang PT PLN (Persero) UP3 Teluk Naga Tangerang. 
Yang merupakan salah satu cabang dari Divisi Bagian Niaga yang ada di PT PLN (Persero) UP3 Teluk Naga Tangerang. Dengan fokus penlitian ini yaitu adalah faktor-faktor penyebab penurunan kinerja karyawan outsourcing bagian pengelolaan piutang di PT PLN (Persero) UP3 Teluk Naga Tangerang, sehingga subjek dalam penelitian ialah karyawan outsourcing itu sendiri serta pihakpihak yang berhubungan langsung. Partisipan yang dijadikan subjek dalam penelitian ini yaitu Supervisor Subbagian Pengelolaan Piutang PT PLN (Persero) UP3 Teluk Naga Tangerang, Koordinator Karyawan Subbagian Pengelolaan Piutang PT PLN (Persero) UP3 Teluk Naga Tangerang, dan perwakilan Karyawan Outsourcing Subbagian Pengelolaan Piutang PT PLN (Persero) UP3 Teluk Naga Tangerang.

Penelitian menggunakan data primer serta data sekunder sebagai sumber data. 'Data primer, yaitu data yang langsung dan segera diperoleh dari data oleh peneliti untuk tujuan yang khusus penelitian (Samsu, $2017 \mathrm{hlm} .95$ ) dengan kata lain data primer adalah data yang diperoleh dari sumber pertama secara langsung melalui proses observasi atau wawancara dengan informan atau partisipan. Data primer didapat dari hasil wawancara langsung dengan informan sedangkan data sekunder yang digunakan didalam penelitian ini berasal dari struktur organisasi serta dokumen yang dimiliki oleh PT PLN (Persero) UP3 Teluk Naga Tangerang.

Teknik pengumpulan data dalam penelitian ini mennggunakan teknik wawancara semi berstruktur, observasi, dan dokumentasi. (Yusuf, 2017 hlm. 152) Mengemukakan bahwa 'wawancara (Interview) ialah proses interaksi dengan pewawancara (interviewer) kemudian mendapatkan sumber informasi atau orang yang diwawancarai (interviewee) dari hasil komunikasi langsung. Menurut Holloway dan Wheeler dalam (Rachmawati, 2017 hlm. 36) penelitian kualitatif umum wawancara tidak berstruktur atau juga semi berstruktur. Pada penelitian akan menggunakan teknik wawancara semi berstruktur yang dimana Pada wawancara ini sekuensi pertanyaan tidaklah sama pada tiap partisipan bergantung pada proses wawancara dan jawaban tiap individu. Namun adanya pedoman wawancara menjamin peneliti dapat mengumpulkan jenis data yang sama dari partisipan. Penelitian dilakukan dengan melakukan wawancara semi terstruktur kepada partisipan yang antara lain ialah; Supervisor, Koordinator Karyawan, dan Perwakilan Karyawan Outsourcing Subbagian Pengelolaan Piutang PT PLN (Persero) UP3 Teluk Naga Tangerang.

Data diobservasi dapat berupa gambaran berkaitan dengan sikap, kelakuan, perilaku, tindakan, juga keseluruhan interaksi antar manusia. data observasi berupa interaksi organisasi maupun pengalaman anggotanya (Raco, 2018 hlm. 37). Observasi dilakukan terhadap langkah-langkah alur proses kerja, serta cara kerja dari karyawan outsourcing bagian pengelolaan piutang PT PLN (Persero) UP3 Teluk Naga Tangerang, dan dokumentasi dilakukan dengan pengambilan foto pada tahapan melakukan wawancara dan observasi untuk meningkatkan kredibilitas dan sebagai bukti fisik serta membantu peneliti saat melakukan validitas data.

Teknik validitas data dalam penelitian menggunakan model triangulasi sumber, dan triangulasi teoritis yaitu mencari data dan informasi yang sama dari subjek lain dan juga membandingkan data yang diperoleh dengan teori-teori yang ada. Dengan kata lain, peneliti menanyakan pertanyaan yang sama dari berbagai sumber untuk perbandingan nanti dan mengonfirmasi data yang sudah didapatkan dengan teori yang ada. bika data dan informasinya benar, maka akan dikumpulkan, begitu pula sebaliknya, bila data dan informasi tersebut salah atau tidak benar maka perlu menggunakan metode triangulasi lain untuk mengecek data dan informasi tersebut.

Teknik analisis data Metode pengumpulan data digunakan yaitu metode observasi yang bertujuan mengamati secara langsung pekerjaan pegawai outsourcing subbagian pengelolaan piutang PT PLN UP3 Teluk Naga pada saat melakukan tindakan penagihan terhadap konsumen. Metode wawancara juga digunakan sebagai metode utama untuk memperoleh informasi lebih lanjut, secara internal dan langsung dari karyawan outsourcing serta partisipan lainnya yang memiliki hubungan dengan karyawan outsourcing serta berperan di subbagian pengelolaan piutang. Peneliti juga menggunakan metode dokumentasi yang digunakan untuk memverifikasi, memvalidasi, mendukung data hasil observasi serta 
wawancara.

Peneliti menyederhanakan perolehan data dan dikumpulkan melalui cara merangkum, memilih, memfokuskan hal penting berkaitan fokus penelitian, proses ini disebut dengan proses reduksi data. Dengan proses tersebut data diperoleh dapat memberikan gambaran lebih jelas, sehinga lebih mudah memahami makna terkandung. Setelah proses reduksi data selesai, data akan disajikan dalam bentuk deskripsi teks naratif deskriptif, sesuai dengan fokus penelitian, sehingga menghasilkan kumpulan informasi yang terstruktur, dan kemudian diperoleh suatu kesimpulan dari informasi tersebut.

\section{HASIL DAN PEMBAHASAN}

Proses wawancara, observasi, dokumentasi dalam menganalisis mengenai faktor-faktor penyebab penurunan kinerja karyawan yang dimana kegiatan penelitian dilakukan pada rentang waktu Mei Sampai Juni 2021. Wawancara dilakukan dengan beberapa subjek dan informan terkait, observasi dilakukan peneliti dengan mengamati seluruh proses kegiatan kerja karyawan outsourcing dalam melakukan tindakan penagihan tunggakan kepada konsumen. Hasil observasi akan menunjukan segala tentang objek penelitian, kondisi yang terjadi di lapangan, cara kerja, hingga pribadi dari karyawan outsourcing .

Pokok pembahasan dilandaskan berdasarkan teori kasmir dalam Kasmir (2016) yang menyatakan terdapat sepuluh faktor yang dapat berdampak terhadap kinerja karyawan antara lain faktor; keterampilan \& keahlian, pengetahuan, rencana kerja, sikap kerja, motivasi kerja, kepemimpinan, beban kerja, kepuasan kerja, loyalitas kesetiaan, serta disiplin kerja.

\section{Keterampilan dan Keahlian}

Pada dasarnya, karyawan memiliki keterampilan serta keahlian sesuai kebutuhan pekerjaan dapat dengan mudah menyelesaikan tugas yang diberikan tanpa hambatan. Pada subbagian pengelolaan piutang tidak dibutuhkannya suatu keahlian khusus, tetapi terdapat beberapa keterampilan dan keahlian dasar yang harus dikuasai dan dibutuhkan oleh karyawan dalam pekerjaannya, yaitu antara lain; instalasi listrik dalam melakukan pemutusan, penyambungan aliran listrik dan penyegelan Kwh, cara berkomunikasi kepada konsumen, serta pemahaman titik koordinat pada maps.

Jawaban yang disampaikan koordinator dalam wawancara menjelaskan lebih terperinci bahwasanya dalam instalasi listrik karyawan harus sebaiknya menguasai bagaimana cara memutus dan menyambung aliran, melakukan penyegelan Kwh. Selain itu karyawan juga perlu untuk menguasai cara membaca titik koordinat lokasi. Dari hasil observasi dan wawancara pada kenyataannya masih terdapat beberapa karyawan outsourcing subbagian pengelolaan piutang yang tidak mengusai sepenuhnya keterampilan dan keahlian dasar yang diperlukan, sehingga menghambat proses penyelesaian pekerjaan.

Berdasarkan uraian jawaban panjang dari hasil wawancara dengan Spv tersebut dapat dianalisis dan disimpulkan, bahwa kurangnya penguasaan keterampilan dan keahlian dasar karyawan outsourcing menjadi salah satu faktor penyebab penurunan kinerja karyawan. Hal tersebut dipicu adanya pandemi covid-19 dimana karyawan yang biasa bekerja secara beregu atau secara berkelompok untuk saling memenuhi kekurangan masing-masing, kini diharuskan bekerja secara individu demi menerapkan SOP protokol kesehatan yang berlaku. Kondisi tersebut menyebabkan karyawan dengan tingkat penguasaan keterampilan dan keahlian dasar yang kurang baik menjadi terhambat dalam menyelesaikan pekerjaannya

\section{Pengetahuan}

Tingkat pengetahuan dimiliki karyawan dalam bidang pekerjaannya akan berpengaruh terhadap bagaimana karyawan dalam melakukan atau menyelesaikan setiap pekerjaan atau tugas-tugas yang diberikan. Dari jawaban yang diungkapkan koordinator karyawan dalam wawancara menunjukan bahwa tingkat pengetahuan karyawan outsourcing subbagian pengelolaan piutang PT PLN (Persero) UP3 Teluk Naga akan pekerjaannya sudah sangat baik, dimana setiap karyawan sudah mengetahui bagaimana respons yang harus diberikan atau dilakukan 
terhadap tunggakan konsumen mulai dari memberikan surat tagihan, melakukan penyegelan, hingga melakukan pemutusan listrik.

Pernyataan dari Supervisor juga menunjukkan bahwa tingkat karyawan sudah baik dan tidak ada pengaruhnya dengan permasalahan penurunan hasil penyelesaian target. Bapak Jefri juga menyampaikan hal yang sama bahwasanya pengetahuan karyawan yang sudah baik tidak ada hubungannya dengan penurunan kinerja karyawan outsourcing subbagian pengelolaan piutang PT PLN (persero) UP3 Teluk Naga.

Dari pernyataan-pernyataan yang diberikan Supervisor subbagian pengelolaan piutang dan kedua koordinator karyawan outsourcing baik dari PT Shiwa maupun PT Kedu Jaya dapat disimpulkan bahwa pengetahuan tentang pekerjaan dari karyawan outsourcing subbagian pengelolaan piutang PT PLN (Persero) UP3 Teluk Naga sudah cukup baik, sehingga tingkat pengetahuan karyawan bukan merupakan faktor penyebab dari penurunan kinerja karyawan pada subbagian pengelolaan piutang PT PLN UP3 Teluk Naga.

\section{Rencana Kerja}

Dalam melaksanakan pekerjaannya setiap karyawan mempunyai rencana kerjanya masing-masing yang dapat mereka terapkan dalam melakukan pekerjaannya. Adanya perencanaan kerja yang diterapakan karyawan sesuai preferensi untuk memudahkan dalam melakukan pekerjaannya menyebabkan tidak adanya permasalahan dalam indikator rencana kerja.

Menurut salah satau karyawan dari sudut pandang karyawan setiap karyawan mempunyai rencana atau cara kerja yang berbeda-beda, dan rencana kerja yang mereka terapkan dalam mengeksekusi pekerjaannya tidak ada hubungannya dengan permasalahan kinerja. Hal itu terbukti dari pernyataan rencana yang digunakan berbeda antara karyawan satau dengan yang lainnya. Dari pernyataan-pernyataan tersebut maka disimpulkan bahwa karyawan memiliki rencana kerja masing-masing yang menurut mereka dapat membantu mempermudah pekerjaannya, dan rencana kerja bukan salah satu faktor penyebab turunnya kinerja karyawan outsourcing subbagian pengelolaan piutang PT PLN UP3 Teluk Naga.

\section{Sikap Kerja}

Sikap kerja yang dimiliki karyawan outsourcing PT PLN (persero) UP3 Teluk Naga akan menunjukkan bagaimana karyawan dalam melakukan setiap pekerjaannya Perkataan dari salah satau coordinator karyawan menggambarkan keberagaman sikap karyawan mulai dari karyawan yang semangat dalam melakukan pekerjaannya, sampai yang malas dalam bekerja. Menurut beliau yang terjadi di lapangan adalah karyawan yang malas untuk melakukan tindakan kunjungan dua kali ke pada konsumen, jika kunjungan pertamanya tidak membuahkan hasil. Dari jawaban dan contoh yang diberikan salah satu koordinator menunjukkan sikap kerja karyawan yang kurang dalam mengusahakan untuk menyelesaikan pekerjaan yang diberikan, beliau juga berasumsi bahwa sikap karyawan yang kurang bertanggung jawab dalam menyelesaikan pekerjaan disebabkan sulitnya pekerjaan itu untuk diselesaikan. Dari pernyataan-pernyataan yang disampaikan koordinator tersebut diungkapkan fakta bahwa sikap kerja satu faktor penyebab penurunan kinerja karyawan sebab masih banyaknya karyawan outsourcing yang tidak mengusahakan menyelesaikan pekerjaannya, bersikap tidak serius dan kurang bertanggung jawab dalam menjalankan target kerja mereka

\section{Motivasi Kerja}

Motivasi kerja dapat menjadi satu faktor mempengaruhi kinerja karyawan, motivasi kerja adalah bentuk dorongan yang menggerakkan dan mengarahkan perilaku seseorang dalam menyelesaikan dan melaksanakan tugas-tugas dari pekerjaannya. Berdasarkan hasil wawancara kepada karyawan menunjukan kemiripan motivasi antar karyawan dalam bekerja, yaitu mencari penghasilan untuk memenuhi kebutuhan hidup. Namun pekerjaan karyawan outsourcing PT PLN (Persero) UP3 Teluk Naga Tangerang memiliki suatu target pencapaian yang harus diselesaikan, maka seharusnya karyawan memiliki tingkat 
motivasi yang tinggi untuk menyelesaikan target pekerjaannya.

Hasil wawancara juga menunjukan rendahnya motivasi karyawan dalam menyelesaikan target pekerjaannya yang disebabkan oleh sulitnya target pekerjaan tersebut untuk diselesaikan, sehingga motivasi karyawan dalam bekerja hanya untuk memenuhi kebutuhan hidup dan bekerja hanya secukupnya saja.

Berdasarkan pernyataan-pernyataan yang ada dapat disimpulkan bahwa motivasi kerja karyawan dapat dipengaruhi oleh tingkat kesulitan kerja. Meningkatnya tingkat kesulitan kerja menyebabkan menurunnya motivasi karyawan dalam menyelesaikan target pekerjaannya, karyawan dengan tingkat motivasi yang rendah lebih memilih untuk menyelesaikan pekerjaan yang hanya bisa dilakukannya saja, hal ini berarti bahwa motivasi kerja merupakan salah satu faktor penyebab penurunan kinerja karyawan outsourcing Subbagian Pengelolaan Piutang UP3 Teluk Naga Tangerang.

\section{Kepemimpinan}

Kepemimpinan yang baik diharapkan dapat memberikan suatu arahan, dorongan, dan perilaku atau contoh yang baik atasan kepada karyawan nya demi mencapai keberhasilan perusahaan. Pada subbagian pengelolaan piutang PT PLN (Persero) UP3 Teluk Naga posisi atasan langsung yaitu adalah supervisor. Dalam hasil wawancara peneliti menemukan adanya perbedaan bentuk arahan, dan dorongan yang diberikan oleh atasan sebelum terjadi fenomena penurunan kinerja karyawan dan saat terjadi adanya fenomena penurunan kinerja karyawan yang mengindikasikan bahwa faktor kepemimpinan merupakan penyebab utama dari fenomena yang terjadi. Pernyataan dari coordinator karyawan mengungkapkan bahwa kepemimpinan merupakan faktor penyebab utama dari penurunan kinerja karyawan outsourcing Subbagian pengelolaan piutang PT PLN UP3 Teluk Naga. Hal ini dikarenakan perbedaan pemberian arahan dari pimpinan atas kepada karyawan yang dipicu oleh pandemi Covid-19. berkurangnya keterlibatan secara langsung antara atasan yang diperlihatkan dari tidak adanya lagi briefing secara tatap muka langsung, kegiatan pengarahan dan pengontrolan yang hanya dilakukan via Whatsapp, hal ini disebabkan oleh protocol yang harus diterapkan karena kondisi Covid-19 Pernyataan dari karyawan dan juga koordinator dalam wawancara menggambarkan pentingnya peran kepemimpinan. dan hadirnya sosok pemimpinan yang membuat karyawan lebih semangat dan termotivasi dalam bekerja, tetapi adanya kondisi penerapan protokol akibat pandemi covid-19 menyebabkan kurangnya interaksi langsung antara atasan dengan karyawan yang menyebabkan berkurangnya juga motivasi karyawan dalam menyelesaikan pekerjaannya. Dari pernyataan-pernyataan tersebut dapat ditarik kesimpulan bahwa berkurangnya interaksi, arahan, dan dorongan langsung dari atasan membawa pengaruh negatif kepada berbagai aspek yang berdampak kepada penurunan kinerja karyawan. Sehingga berkurangnya sosok Kepemimpinan menjadi salah satu faktor yang menyebabkan turunnya kinerja karyawan outsourcing Subbagian pengelolaan piutang PT PLN UP3 Teluk Naga.

\section{Beban Kerja}

Beban kerja yang berlebihan umumnya akan berdampak buruk pada karyawan, menyebabkan kelelahan fisik dan mental serta menimbulkan reaksi emosional. Pada wawancara yang dilakukan peneliti akan bertanya kepada partisipan tentang bagaimana tingkat kesulitan pekerjaan karyawan subbagian pengelolaan piutang PT PLN UP3 Teluk Naga, dan menganalisis apakah beban kerja yang ada menjadi penyebab fenomena penurunan kinerja. Ungkapan dari salah satau karyaan dalam wawancara menjelaskan tingkat kesulitan pekerjaan pada subbagian pengelolaan piutang yang sangat sulit, sehingga dapat diartikan bahwa karyawan memiliki beban kerja yang besar. Pernyataa Supervisior mununjukkan signifikansinya penurunan kinerja karyawan subbagian pengelolaan piutang PT PLN UP3 Teluk Naga akibat kenaikan tingkat kesulitan karyawan dalam melakukan pekerjaannya serta menunjukkan tingkat kesulitan kerja karyawan subbagian pengelolaan piutang yang dipengaruhi oleh tingkat kemampuan ekonomi konsumen dalam membayar tagihan listrik, 
digambarkan dari konsumen area teluk naga yang merupakan konsumen dengan tingkat ekonomi menengah ke bawah dengan mayoritas konsumen adalah pegawai pabrik, dan petani. Akibat pandemi covid-19 tingkat kemampuan konsumen dalam membayar tagihan listrik menurun, yang menjadi penyebab meningkatnya tunggakan listrik, dan ketidakmampuan konsumen dalam membayar tagihan listrik menyebabkan sulitnya karyawan dalam menyelesaikan pekerjaan. Dari pernyataan-pernyataan tersebut dapat dianalisis bahwa adanya peningkatan tingkat kesulitan kerja karyawan pada tahun 2020 dikarenakan kondisi covid-19, hal ini dapat diartikan bahwa beban kerja karyawan juga semakin berat. Sehingga dapat disimpulkan beban kerja karyawan subbagian pengelolaan piutang PT PLN UP3 Teluk Naga yang meningkat menjadi salah satu faktor penyebab terjadinya fenomena permasalahan penurunan kinerja.

\section{Kepuasan Kerja}

Kepuasan kerja mencerminkan perasaan tentang pekerjaan, yang dapat dilihat dari sikap karyawan atas pekerjaan dan sikap terhadap sesuatu pada lingkungan kerja. Dalam wawancara yang dilakukan salah satu karyawan mengungkapkan kurang puasnya beliau terhadap pekerjaannya di Subbagian Pengelolaan Piutang dari ungkapan tersebut menunjukkan bahwa ketidakpuasan karyawan subbagian pengelolaan piutang PT PLN UP3 Teluk Naga dipengaruhi oleh kesulitan pekerjaannya yang terlalu berat. Karyawan yang merasa tidak puas akibat pekerjaannya yang terlalu berat menyebabkan karyawan kurang semangat dalam bekerja.

Berdasarkan pernyataan-pernyataan yang diungkapkan oleh partisipanyaitu para karyawan dan supervisor menunjukkan turunnya tingkat kepuasan kerja karyawan outsourcing subbagian pengelolaan piutang PT PLN (Persero) UP3 terhadap pekerjaannya yang dikarenakan meningkatnya tingkat kesulitan pekerjaan. Kepuasan kerja karyawan erat kaitannya dengan kinerja karyawan. Karyawan outsourcing yang tak puas atas pekerjaan cenderung mengantongi semangat kerja dan sikap partisipasi kerja yang rendah, analisis tersebut menunjukkan bahwa menurunnya kepuasan kerja karyawan outsourcing subbagian pengelolaan piutang merupakan salah satu faktor yang menyebabkan penurunan kinerja.

\section{Loyalitas Kesetiaan}

Dari hasil penelitian ditemukan bahwa tingkat loyalitas kesetiaan karyawan outsourcing subbagian pengelolaan piutang terbilang rendah karena karyawan yang berpikir jika mereka memiliki kesempatan atau pilihan pekerjaan lain, maka mereka akan lebih memilih untuk pindah, salah satu karyawan mengungkapkan keinginannya untuk bekerja di aera PLN lainnya atau karyawan yang menginginkan untuk bekerja di bagian lain dikarenakan pekerjaan tersebut lebih mudah untuk dilakukan dibandingkan dengan pekerjaannya sekarang.

Loyalitas karyawan yang rendah membuat karyawan outsourcing subbagian pengelolaan piutang bekerja secara secukupnya saja, Ketika loyalitas menjadi berkurang maka akan berdampak pada keterlibatan karyawan, karyawan outsourcing tidak merasa terdorong untuk terlibat dan berkontribusi secara maksimal dalam menyelesaikan target pekerjaan yang diberikan, sehingga dapat disimpulkan loyalitas kesetiaan karyawan outsourcing subbagian pengelolaan yang menurun merupakan salah satu faktor penyebab penurunan kinerja pada subbagian pengelolaan piutang.

\section{Disiplin Kerja}

Rendahnya kedisiplinan karyawan outsourcing subbagian pengelolaan piutang merupakan suatu permasalahan lama yang ada di subbagian pengelolaan piutang, dilihat dari adanya karyawan yang terlambat, menunda pekerjaan, tidak menggunakan seragam saat bekerja, pernyataan dari koordinator karyawan dalam wawancara mengkonfirmasi rendahnya tingkat kedisiplinan karyawan yang ada dilihat dari karyawan yang menunda-nunda pekerjaan dan masih adanya karyawan yang tidak menggunakan seragam.

Penjelasan dari koordinator karyawan menjelaskan bahwa karyawan yang tidak disiplin dan menunda-nunda pekerjaan memang dapat mempengaruhi kinerja, tetapi 
kebiasaan tersebut dan kedisiplinan yang masih kurang baik merupakan hal yang sudah lama ada pada seluruh karyawan lapangan termasuk karyawan outsourcing subbagian pengelolaan piutang. Berdasarkan hasil analisis yang didapatkan dari observasi dan jawaban wawancara tersebut, maka rendahnya disiplin kerja secara spesifik bukan faktor penyebab terjadinya penurunan kinerja pada tahun 2020. Dikarenakan tingkat disiplin karyawan yang tidak berubah kearah yang lebih buruk maupun ke arah lebih baik saat terjadinya permasalahan penurunan kinerja karyawan outsourcing subbagian pengelolaan piutang PT PLN UP3 Teluk Naga Tangerang.

\section{KESIMPULAN}

Hasil dari penelitian yang dilakukan menemukan bahwa fenomena permasalahan penurunan hasil kerja karyawan outsourcing subbagian pengelolaan piutang PT PLN (persero) UP3 Teluk Naga disebabkan tiga faktor utama yang saling memiliki keterikatan terhadap faktor lainnya dengan perannya masing-masing sebagai penyebab dari

\section{DAFTAR REFERENSI}

Adamy, M. (2016). MANAJEMEN SUMBER DAYA MANUSIA Teori, Praktik dan Penelitian (Vol. 106, Issue 12). Unimal Press.

Dessler, G. (2017). Human Resources Management 15th Ed. In Fortune.

Elbadiansyah. (2019). Manajemen Sumber Daya Manusia (C. I. Gunawan (ed.)). CV IRDH.

Haryono, S. (2018). Manajemen Kinerja SDM Teori \& Aplikasi. (1st ed., Vol. 4, Issue 3). Luxima Metro Media.

Indrasari, M. (2017). Kepuasan Kerja dan Kinerja Karyawan Tinjauan dari Dimensi Iklim Organisasi , Kreatifitas Individu, dan Karakteristik Pekerjaan. Yogyakarta: Indomedia Pustaka, 1-85.

Kasmir. (2016). Manajemen Sumber Daya Manusia Teori dan Praktik. Rajawali Pers.

Kawiana, I. G. P. (2020). Manajemen Sumber Daya Manusia, "MSDM" Perusahaan. In UNHI Press (Vol. 4, Issue 3). penurunan kinerja yang dipicu dengan adanya kondisi pandemic Covid-19, faktor-faktor tersebut adalah kurangnya kemampuan dan keahlian dasar yang dimiliki oleh karyawan. Kondisi Covid-19 yang mengharuskan pembatasan pembagian tim kerja menyebabkan karyawan yang tidak memiliki kemampuan dan keahlian dasar instalasi listrik hanya bisa mengerjakan pekerjaan secara terbatas.

Berkurangnya interaksi secara langsung antara atasan dan karyawan akibat kondisi pandemi covid-19, membuat karyawan kehilangan sosok pemimpin yang menjadikan sikap kerja karyawan menjadi tidak semangat, kurang termotivasi, dan kurang bertanggung jawab dalam menyelesaikan target pekerjaan yang sudah ditentukan. Meningkatnya tingkat kesulitan kerja akibat kondisi pandemi Covid19 yang menyebabkan beban kerja karyawan outsourcing terlalu tinggi mempengaruhi secara negatif dan menurunkan tingkat motivasi karyawan, tingkat kepuasan kerja karyawan, hingga rasa loyalitas kesetiaan karyawan dalam bekerja di subbagian pengelolaan piutang PT PLN UP3 Teluk Naga Tangerang.

Lian, B. (2017). KEPEMIMPINAN DAN KUALITAS KINERJA PEGAWAI (D. Wardiah \& D. Nuzulia (eds.); 1st ed.). NoerFikri Offset.

Mondy, R. W., \& Martocchio, J. J. (2016). Human Resource Management, Global Edition. In IOSR Journal of Business and Management Ver. I.

Rachmawati, I. N. (2017). Pengumpulan Data Dalam Penelitian Kualitatif: Wawancara. Jurnal Keperawatan Indonesia, 11(1), $35-40$.

Raco, J. (2018). Metode penelitian kualitatif: jenis, karakteristik dan keunggulannya.

Rivai, V., \& Segala, E. J. (2011). Manajemen Sumber Daya Manusia untuk Perusahaan dari Teori ke Praktik. PT. Raja Grafindo, Persada.

Samsu. (2017). Metode Penelitian: Teori dan Aplikasi Penelitian Kualitatif, Kuantitatif, Mixed Methods, serta Research and Development. In Diterbitkan oleh: Pusat Studi Agama dan Kemasyarakatan (PUSAKA). 
Sinambela, L. P. (2016). Membangun tim kerja yang solid untuk meningkatkan kinerja. PT BUMI AKSARA.

Yusuf, M. (2017). Metode Penelitian

Kuantitatif, Kualitatif \& Penelitian
Gabungan. In KENCANA (4th ed., Vol. 4, Issue 3). KENCANA.

\section{Copyrights}

Copyright for this article is retained by the author(s), with first publication rights granted to the journal.

This is an open-access article distributed under the terms and conditions of the Creative Commons Attribution license (http://creativecommons.org/licenses/by/4.0/). 